\title{
NUMERICAL INVESTIGATION OF WINGLET ANGLES INFLUENCE ON VORTEX SHEDDING
}

\author{
M L Kalyana Chakravarthy ${ }^{1}$, U. Sudhakar ${ }^{2}$, Nirmith Kumar Mishra ${ }^{3}$ \\ ${ }^{I}$ PG Scholar, Marri Laxman Reddy Institute of Technology \& Management, Dundigal, Hyderabad \\ ${ }^{2}$ Associate Professor, Marri Laxman Reddy Institute of Technology \& Management, Dundigal, Hyderabad \\ ${ }^{3}$ Assistant Professor, Marri Laxman Reddy Institute of Technology \& Management, Dundigal, Hyderabad
}

\begin{abstract}
Wingtip devices are usually intended to improve the efficiency of fixed-wing aircraft. There are several types of wing tip devices, and although they function in different manners, the intended effect is always to reduce the aircraft's drag by partial recovery of the tip vortex energy. Wingtip devices can also improve aircraft handling characteristics and enhance safety for following aircraft. Such devices increase the effective aspect ratio of a wing without materially increasing the wingspan.

The purpose of this project is to analyse different types of winglets using Auto CAD, GAMBIT and FLUENT and then, to find out what happens when winglets are linked to wingtips and to study about the aerodynamic properties of spiroid winglets which are still under research. One wing model without winglet and three wing models with winglets were created and drawn in Auto CAD and they were meshed in GAMBIT using geometry data gathered from research papers. Those models were read into Fluent where flow boundary conditions were applied.

The wing without winglet, the wings with spiroid winglets and the wings with other kinds of winglets performance were analyzed in several angles of attack and the drag coefficient was compared when the aircraft is taking off. Wingtip vortices from models were checked, studied and compared. The best winglet model reduces drag coefficient and wingtip vortices from wing without winglet model and it will be pointed out at the end of this project.
\end{abstract}

\section{INTRODUCTION}

Since the 1970s, when the price of aviation fuel began spiralling upward, airlines and aircraft manufactures have looked at many ways to improve the operating efficiency of their aircraft. Winglets have become one of the industry's most visible fuel saving technologies and their use continues to expand. Moreover, they can reduce fuel consumption about $4 \%$ in many flights when the distance to crossing is more than $1800 \mathrm{~km}$. Winglets are vertical extensions of wingtips that improve an aircraft's fuel efficiency and cruising range. Designed as small airfoils, they reduced the aerodynamic drag associated with vortices that develop at the wingtips. If aircraft's fuel efficiency goes down means drag coefficient is reduced (Marty Curry, 2008). Drag coefficient reduction will be checked and compared when winglets are used. For that, three wings models with different types of winglets will be analyzed in different angles of attack. Besides, a wing model without winglet will be studied and the results can be compared. The wing was made of a naca 2415 airfoil. The drag coefficient reduction has similarities to wingtip vortex which is developed when the aircraft moves through the air. Therefore, wingtip vortex will be analyzed and we may check how the vorticity magnitude can be reduced with winglets.

A-330 wing was built and the winglets were fixed at the wingtip. The wing was created and drawn in AutoCAD and it was imported to Gambit 2.4.6 to mesh the different models. I would say mesh models is one of the worst and difficult task in my project, indeed. The different types of wings with winglets and without winglet were analyzed and compared in Fluent 6.3.26. Several tables, diagrams or figures will be used to show the vorticity magnitude, the wingtip vortices and the drag coefficient reduction. Blended winglet, wingtip fence and circular winglet have been used to demonstrate wingtip vortex and drag coefficient go down when they are used in the aircrafts. Airfoil 0012 was used to create blended winglet and wingtip fence. That is a symmetrical airfoil so it must be used in my models since it is not able to develop a high lift coefficient which would make it wrong to winglet performance. Finally, a winglet will be chosen due to drag coefficient's reduction when that winglet will be working at the wingtip. Furthermore, as this winglet has been previously picked, I will make a point linked to it, and the drag coefficient reduction showed in a final table.

\section{SCOPE OF THE PROJECT}

When the aircraft moves through the air, it results into the production of wingtip vortices due to its own lifting. These wingtip vortices are higher as the aircraft lift increases. If winglets are fixed to wingtips, then such wingtip vortex goes down and the aircraft performance will turn out to be better. I have hardly emphasized on the analyses and wingtip vortex development and performance.

When winglets are used, drag coefficient decreases since wingtip vortices are broken or reduced by winglets. The drag coefficient reduction and why it is reduced will be the main aim to study and develop in my project. 
Finally, I would like to demonstrate and prove winglet works more efficiently and, in addition, to show how drag coefficient can be reduced. That is the main reason why aircraft's fuel efficiency can be improved if winglets are linked to wingtips.

\section{TYPES OF WINGLETS}

In general any wingtips that not end the wing simply horizontally are considered as some kind of a winglet. Even though in strictly technical terms Wingtip Fences are not real extensions of the wing, and Raked Wingtips do not have a vertical part, they are still widely considered as winglet variants. We have many types of winglets like wingtip fences, blended winglets, spiroid winglets, circular winglets and raked wingtips. The different types of winglets are explained showing various images and commenting on the aircraft in which they are used.

\section{COMPUTATIONAL FLUIDS DYNAMICS (CFD)}

Fluid mechanics is the branch of continuum mechanics (which in turn is a branch of physics) that studies the movement of fluids (gases and liquids) and the forces that cause them. The key feature that defines the fluid is its inability to withstand shear forces (causing lacking definite form). It also examines the interactions between the fluid and the boundary that limits.

The governing equations of fluid mechanics all are obtained by applying the conservation principles of mechanics and thermodynamics to fluid volume. To generalize we use the Reynolds transport theorem and the theorem of divergence (or Gauss) for the equations in a form more useful for the Eulerian formulation.

The three fundamental equations are the continuity equation, the equation of momentum, and the equation of energy conservation. These equations can be integrated in their design or in differential form, depending on the problem. This set of equations given in differential form is also called Navier-Stokes equations.

There is no general solution to this set of equations due to their complexity, so that for each specific problem of fluid mechanics study these equations are looking for simplifications that facilitate the resolution of the problem. In some cases it is possible to obtain an analytical solution, so we have to use computer-generated numerical solutions. This branch of fluid mechanics is called computational fluid dynamics. The equations are: continuity equation, equation of momentum and equation of energy conservation.

$$
\begin{gathered}
\frac{\partial}{\partial t}(\rho v)+\nabla \cdot(\rho \vee \otimes v)=\rho f+\nabla \cdot \tau \\
\rho \frac{D}{D t}^{e+} \frac{1}{2}_{v^{2}}=-\nabla \cdot(p v)+\nabla \cdot\left(\tau^{\prime} \cdot v\right)+\rho f \cdot v+\nabla \cdot(\kappa \nabla T)
\end{gathered}
$$

The Navier-Stokes equation describing the fluid motion and is related to the Reynolds number of fluid through the fluid viscosity, being $\rho$ is the fluid density, $v$ the velocity and pressure $\mathrm{P}$.

The computational fluid dynamics (CFD) is a branch of fluid mechanics that uses numerical methods and algorithms to solve and analyze problems on the flow of substances. Computers are used to perform millions of calculations required to simulate the interaction of fluids and gases with surfaces designed for engineering complex. Even with simplified equations and high-performance supercomputers, only approximate results can be achieved in many cases. Ongoing research, however, allows the incorporation of software that reduces the speed of calculation as well as the margin of error in analyzing situations while allowing more complex fluids such as transonic and turbulent flows. The verification of the data obtained by CFD is usually carried out in wind tunnels or other physical scale models.

The main elements in computational fluid dynamics (CFD) are:

-Discretization of continuous flow, the field variables ( $p, v$, w...) are approximated by a finite number of values at points called nodes.

-The equations of motion are also discretized approximate function values at the nodes. -The systems of algebraic equations are solved and we obtain the values of the variables in the nodes.

The computational fluid dynamics has been used in a large number of engineering disciplines, such as aerodynamics, ship hydrodynamics, engines or combustion. The results of a computational fluid study are similar to those we obtained experimentally in a wind tunnel: they both represent sets of data obtained from a given flow, with Mach number, Reynolds, etc. However, a wind tunnel is a very expensive, large, heavy and difficult to transport. In addition, requires the construction of a model, usually to scale, for study in the tunnel. With the use of computers, however, many of these problems become insignificant: we can design our object of study through computer design, and somehow, we have at our disposal a "transportable wind tunnel" always ready.

Another reason for using CFD is that while in an experiment can only take action in a limited number of points and instants of time, using a computer, we know the parameters we are interested at any point and instant of time.

\section{COMPUTATIONAL PROCESS}

A CFD based software Fluent 6.3.26 has been used for analyzing the different types of winglets. This report presents various steps. AUTO CAD software does CAD generation and Hypermesh does mesh generation. 


\section{CAD GENERATION}

Auto CAD software is used to create the 3D Design. As per the provided geometrical dimensions and tolerances by using the various options in the software the $3 \mathrm{D}$ CAD has been generated.

Table.1: wing areas.

\begin{tabular}{|c|c|c|c|c|}
\hline Wing & $\begin{array}{c}\text { No } \\
\text { winglet }\end{array}$ & $\begin{array}{c}\text { Circular } \\
\text { winglet }\end{array}$ & $\begin{array}{c}\text { Wingtip } \\
\text { fence }\end{array}$ & $\begin{array}{c}\text { Blended } \\
\text { winglet }\end{array}$ \\
\hline $\begin{array}{c}\text { Area } \\
\left(m^{2}\right)\end{array}$ & 321.96 & 328.32 & 323.4 & 325.97 \\
\hline
\end{tabular}

\section{MESH GENERATION}

GAMBIT solver is used to generate the Mesh there two steps in this process

- Surface mesh generation

- Volumes mesh generation.

\section{SOLUTION PROCCESS}

- Read Mesh.

- Physics definition- Implicit, Unsteady state.

- Models $\rightarrow$ Viscous. We must use k- $\omega$ SST (Shear Stress Transport).

- Material Properties - Ideal gas to take into account compressibility effects.

- Operating Conditions. Operating Pressure equals $0 \mathrm{~Pa}$.

- Boundary Conditions. Under zone, we select far field. In the volume control (wing tunnel), the surface link to the wing is wall. The rest of surfaces are pressure far field. We set Mach Number equals 0.85 (254 m/s cruise velocity), Pressure equals $22700 \mathrm{~Pa}$ and Temperature $223 \mathrm{~K}$, according to International Standard Atmosphere (ISA)

- Scheme (solver)

- Solution controls - Numerical and Physical.

- Monitors - Graphical and Parametrical.

- Initialization.

- Solution - Time step size: it is the time that happens between consecutives calculus. Number of Time Steps: it is the amount of times that the software makes the same calculus, decreasing mistake made.

\section{RESULTS AND DISCUSSION}

In this section, results from Fluent will be shown and discussed. Wingtip vortex development and performance will be checked in the first part of this section. To do that, we are going to study the different wings from several angles of attack between 0 and 16 degrees.

\section{WINGLETS PERFORMANCE}

When winglets are linked to wingtips, aircraft designers are looking for drag coefficient reduction and therefore, fuel consumption decreases. The wingtip vortices are responsible for the appearance of a drag coefficient component, induced drag coefficient $C d i$. In this section, I am going to try to demonstrate how wingtips vortices are reduced when winglets are used. In order to do that, control zones will be used to measure the vorticity magnitude in the five wing models. The models will be analysed in different angles of attack, between 4 and 12 degrees.

\section{WINGLETS PERFORMANCE AT $4^{\circ}$}

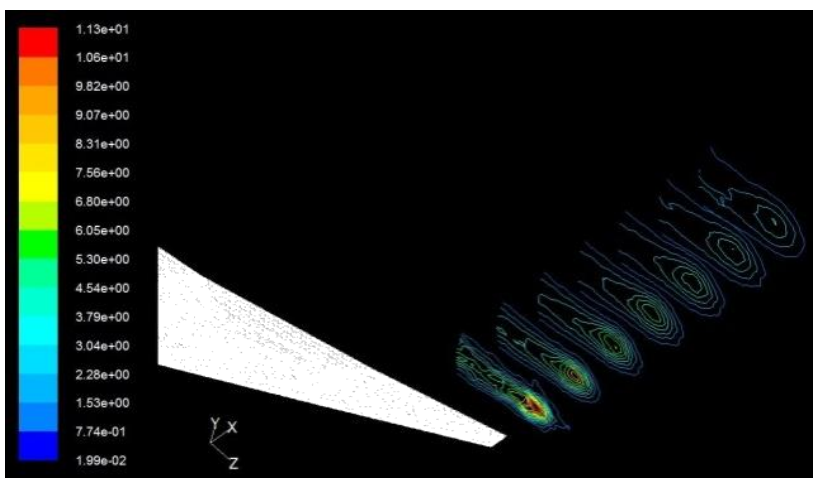

Fig 1: Contours of vorticity magnitude $4^{\circ}$. No winglet

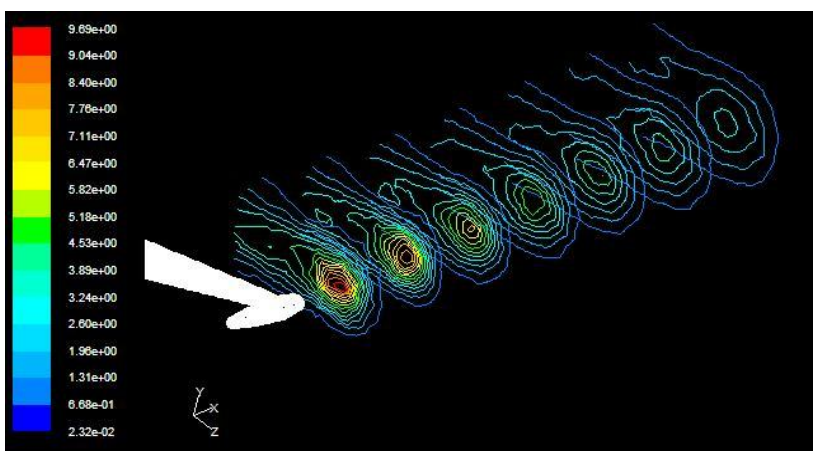

Fig 2: Contours of vorticity magnitude $4^{\circ}$. Circular winglet

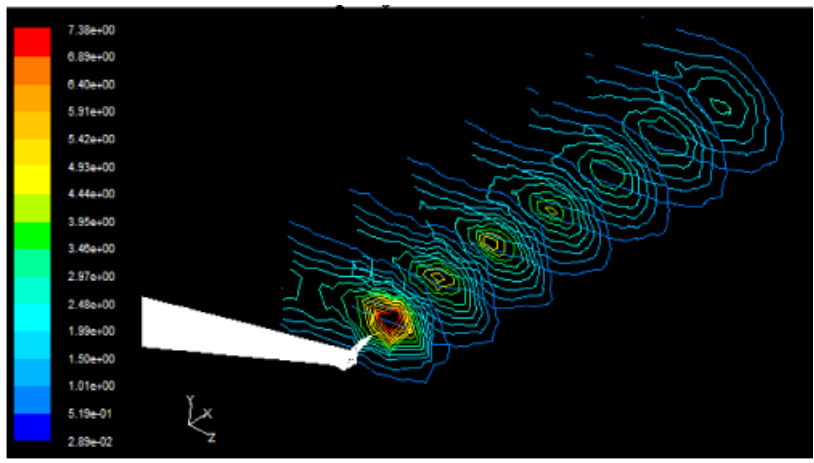

Fig 3: Contours of vorticity magnitude $4^{\circ}$. Wingtip fence

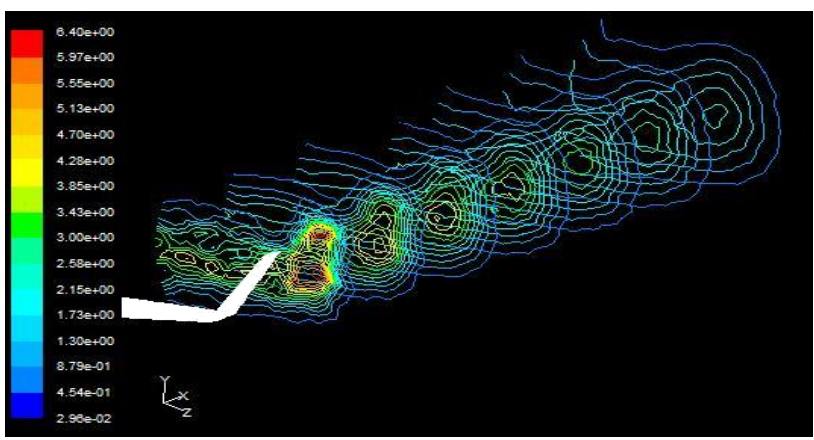

Fig 4: Contours of vorticity magnitude at $4^{\circ}$. Blended winglet 
Table.2 : Total sum of vorticity magnitude (1/s) at $4^{\circ}$ in control zones.

\begin{tabular}{|l|l|l|l|l|l|l|l|}
\hline Wing model & Zone-1 & Zone-2 & Zone-3 & Zone-4 & Zone-5 & Zone-6 & Zone-7 \\
\hline $\begin{array}{l}\text { Without } \\
\text { winglet }\end{array}$ & 2012.3 & 1744.13 & 1646.84 & 2917.71 & 1594.25 & 1488.56 & 1434.83 \\
\hline $\begin{array}{l}\text { Circular } \\
\text { winglet }\end{array}$ & 1827.1 & 1596.89 & 1524.99 & 1368.36 & 1310.32 & 1248.38 & 1205.94 \\
\hline $\begin{array}{l}\text { Wingtip } \\
\text { fence }\end{array}$ & 1576.5 & 1455.18 & 1423.3 & 1386.76 & 1335.6 & 1272.44 & 1194.28 \\
\hline $\begin{array}{l}\text { Blended } \\
\text { winglet }\end{array}$ & 1786.1 & 1593.06 & 1539.53 & 1486.31 & 1433.71 & 1371.18 & 1321.74 \\
\hline
\end{tabular}

\section{WINGLETS PERFORMANCE AT $8^{\circ}$}

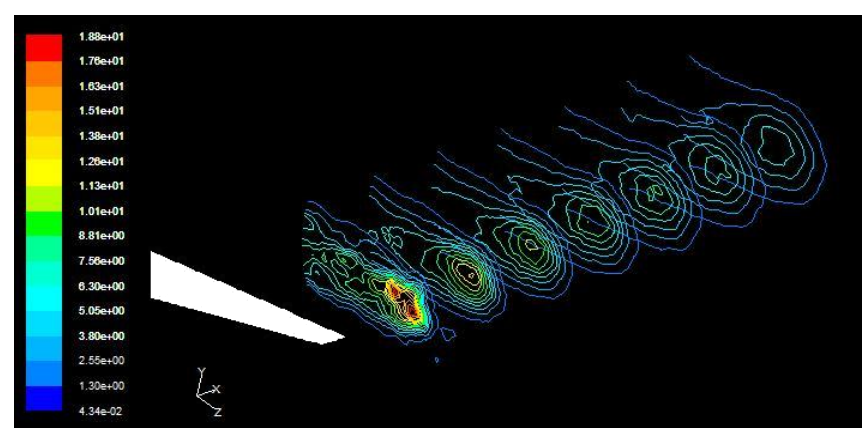

Fig 5: Contours of vorticity magnitude $8^{\circ}$. No winglet

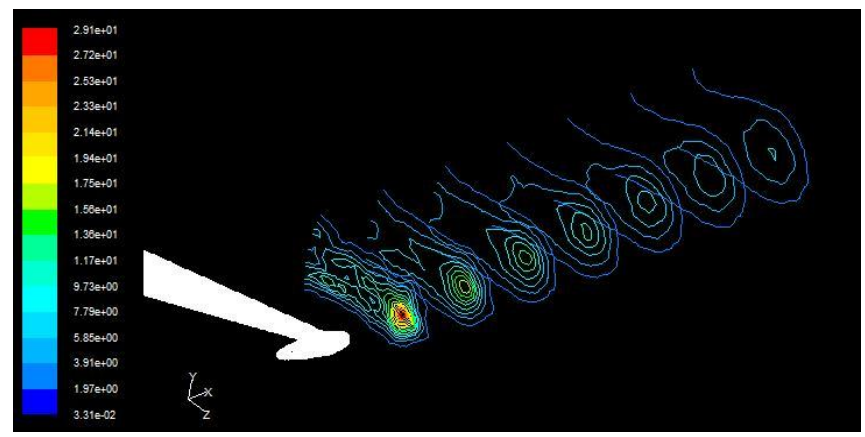

Fig 6: contours of vorticity magnitude $8^{\circ}$. Circular winglet

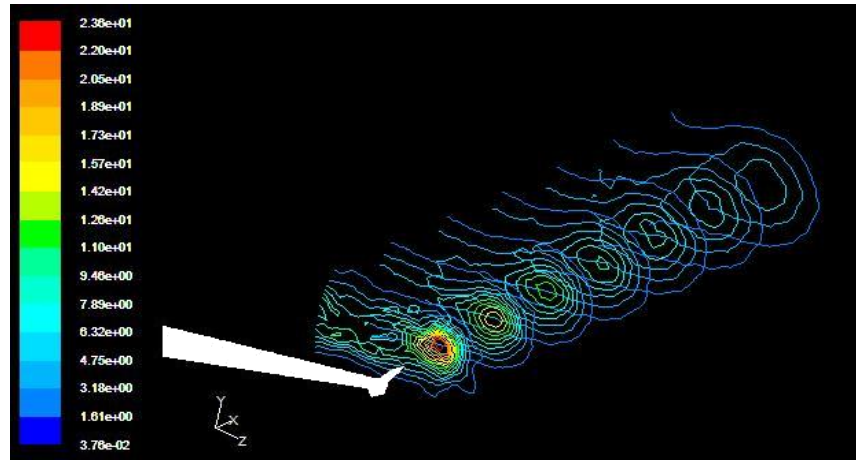

Fig 7: contours of vorticity magnitude $8^{\circ}$. Wingtip fence

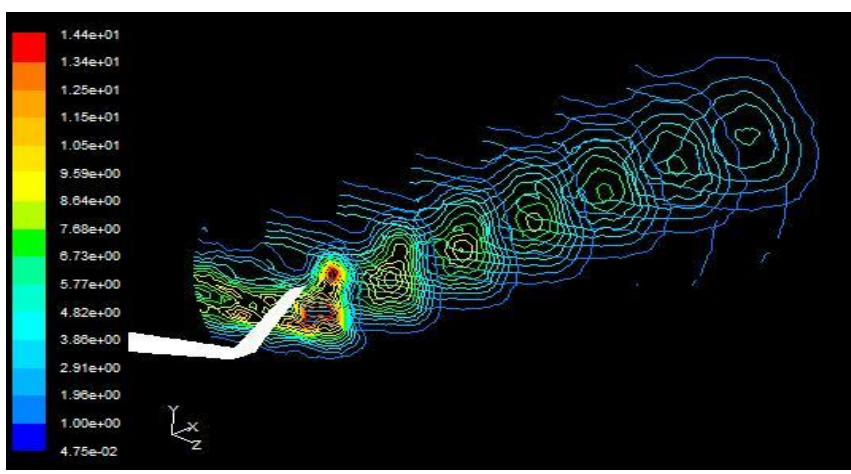

Fig 8: contours of vorticity magnitude $8^{\circ}$. Blended winglet

Table.3 : Total sum of vorticity magnitude $(1 / \mathrm{s})$ at $8^{\circ}$ in control zones.

\begin{tabular}{|l|l|l|l|l|l|l|l|}
\hline Wing model & Zone-1 & Zone-2 & Zone-3 & Zone-4 & Zone-5 & Zone-6 & Zone-7 \\
\hline $\begin{array}{l}\text { Without } \\
\text { winglet }\end{array}$ & 3668.25 & 3223.89 & 3109.14 & 2917.71 & 2925.78 & 2812.71 & 2669.59 \\
\hline $\begin{array}{l}\text { Circular } \\
\text { winglet }\end{array}$ & 3536.26 & 2993.61 & 2827.98 & 2721.55 & 2628.22 & 2510.58 & 2400.33 \\
\hline $\begin{array}{l}\text { Wingtip } \\
\text { fence }\end{array}$ & 3297.4 & 2821.4 & 2697.23 & 2620.41 & 2548.32 & 2446.13 & 2353.61 \\
\hline $\begin{array}{l}\text { Blended } \\
\text { winglet }\end{array}$ & 3032.51 & 2663.86 & 2556.79 & 2511.77 & 2433.79 & 2329.23 & 2148.17 \\
\hline
\end{tabular}




\section{WINGLETS PERFORMANCE AT $12^{\circ}$}

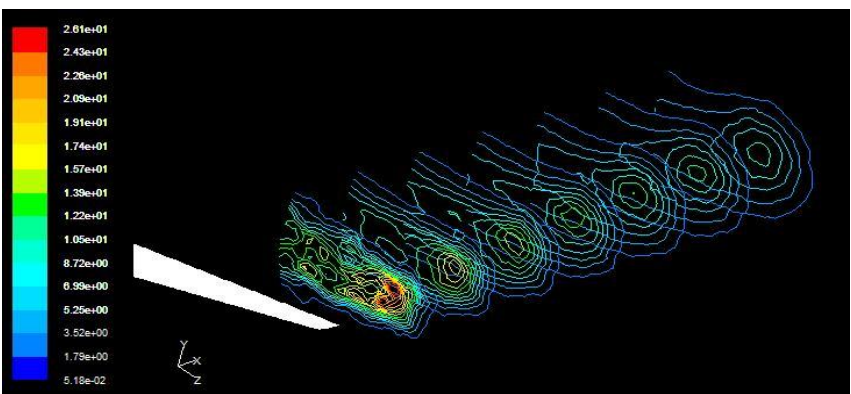

Fig 9: Contours of vorticity magnitude $12^{\circ}$. No winglet

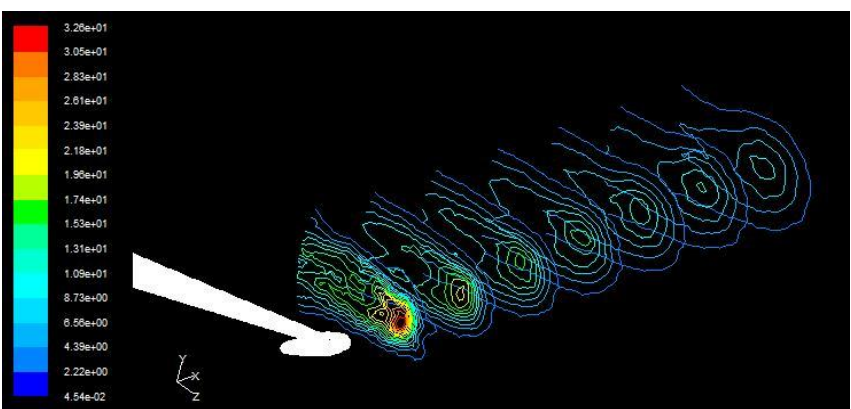

Fig 10: Contours of vorticity magnitude $12^{\circ}$. Circular winglet

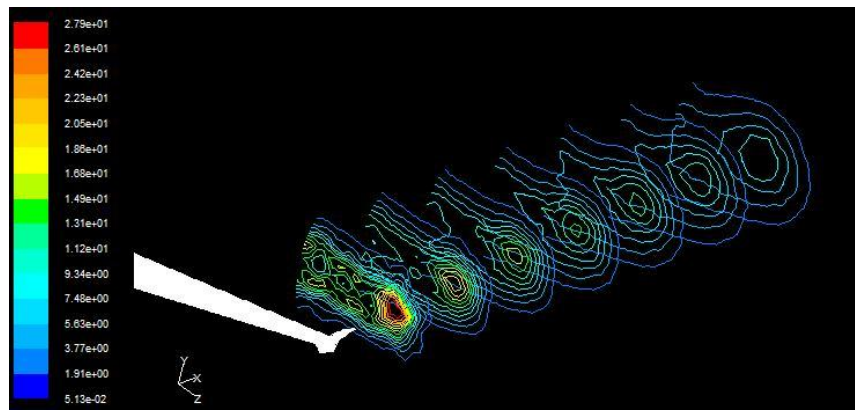

Fig 11: Contours of vorticity magnitude $12^{\circ}$. Wingtip fence

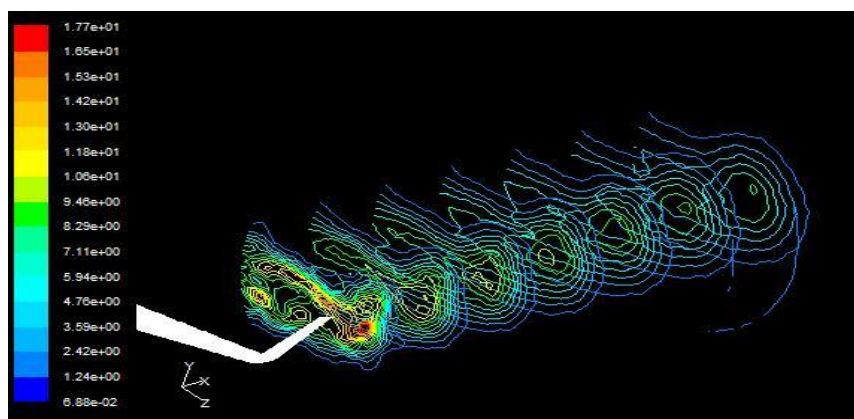

Fig 12: Contours of vorticity magnitude $12^{\circ}$. Blended winglet

Table.4 : Total sum of vorticity magnitude (1/s) at $12^{\circ}$ in control zones.

\begin{tabular}{|l|l|l|l|l|l|l|l|}
\hline \multicolumn{1}{|c|}{ Wing model } & Zone-1 & Zone-2 & Zone-3 & Zone-4 & Zone-5 & Zone-6 & Zone-7 \\
\hline $\begin{array}{l}\text { Without } \\
\text { winglet }\end{array}$ & 6133.68 & 5185.92 & 4890.39 & 4710.73 & 4553.77 & 4381.43 & 4171.45 \\
\hline $\begin{array}{l}\text { Circular } \\
\text { winglet }\end{array}$ & 5900.48 & 4893.3 & 4530.3 & 4297.28 & 4105.32 & 3904.47 & 3718.92 \\
\hline $\begin{array}{l}\text { Wingtip } \\
\text { fence }\end{array}$ & 5430.57 & 4692.14 & 4498.31 & 4361.97 & 4237.1 & 4075.23 & 3854.51 \\
\hline $\begin{array}{l}\text { Blended } \\
\text { winglet }\end{array}$ & 5307.19 & 4410.26 & 4158.24 & 4007.91 & 3878.88 & 3734.62 & 3578.11 \\
\hline
\end{tabular}

As can be seen from tables 2 until 4, the minimum total sum of vorticity magnitude value is produced in wing models with wingtip fence or blended winglet. The maximum value of total sum of vorticity magnitude is always produced in wing model without winglet. Furthermore, the second maximum value of total sum of vorticity magnitude is always produced by wing model with circular winglet. With an angle of attack of 4 degrees, wingtip fence is able to get the highest wingtip vortex reduction in control zones. Nevertheless, blended winglet works better at 8 and 12 degrees. Blended winglet works better at $16^{\circ}$ again, table not reproduced. To measure sum of vorticity magnitude, we must use report $\rightarrow$ surface integrals option into Fluent. Once there, report type $\rightarrow$ sum, field variable $\rightarrow$ velocity $\rightarrow$ vorticity magnitude and finally, surfaces $\rightarrow$ control zones .It is clear; winglets are able to reduced wingtip vortex vorticity magnitude. If wingtip vortex is reduced, the induced drags associated with wingtip vortices development goes down and therefore, drag decreases and aircraft's performance is improved. We can check drag coefficient improvement in section 5.5. In the next section, an attempt to explain how winglets reduced wingtip vortex will be made.

\section{DRAG COEFFICIENT IMPROVEMENT}

The main aim of my project is to check how winglets are able to reduced drag coefficient. The following tables show wing models drag coefficient is reduced when winglets are linked to wingtips with different angles of attack, between $4^{\circ}$ and $16^{\circ}$. 
Table.5: aerodynamic coefficients. Without winglet.

\begin{tabular}{|l|l|l|l|l|l|}
\hline Angle of Attack & Lift $(\mathrm{KN})$ & Drag $(\mathrm{KN})$ & $C d$ & $C L$ & $C L / C d$ \\
\hline $4^{\circ}$ & 191.31111 & 17.4328 & 0.014612 & 0.160368 & 10.9745 \\
\hline $8^{\circ}$ & 373.99611 & 36.0350 & 0.030215 & 0.313499 & 10.3807 \\
\hline $12^{\circ}$ & 523.08733 & 67.2566 & 0.056377 & 0.438477 & 7.77742 \\
\hline $16^{\circ}$ & 633.51104 & 113.1905 & 0.094881 & 0.531038 & 5.59968 \\
\hline
\end{tabular}

Table.6: aerodynamic coefficients. Circular winglet.

\begin{tabular}{|l|l|l|l|l|l|}
\hline Angle of Attack & \multicolumn{1}{|c|}{ Lift $(\mathrm{KN})$} & $\operatorname{Drag}(\mathrm{KN})$ & $C d$ & $C L$ & $C L / C d$ \\
\hline $4^{\circ}$ & 193.70024 & 17.9516 & 0.014727 & 0.158912 & 10.7901 \\
\hline $8^{\circ}$ & 374.85585 & 36.9668 & 0.030380 & 0.308125 & 10.1429 \\
\hline $12^{\circ}$ & 527.00923 & 69.6431 & 0.057239 & 0.433225 & 7.56861 \\
\hline $16^{\circ}$ & 634.46797 & 118.0409 & 0.097027 & 0.521512 & 5.37489 \\
\hline
\end{tabular}

Table.7: aerodynamic coefficients. Blended winglet.

\begin{tabular}{|l|l|l|l|l|l|}
\hline Angle of Attack & Lift $(\mathrm{KN})$ & $\operatorname{Drag}(\mathrm{KN})$ & $C d$ & $C L$ & CL/Cd \\
\hline $4^{\mathrm{o}}$ & 191.9359 & 17.4708 & 0.014578 & 0.160070 & 10.9802 \\
\hline $8^{\circ}$ & 373.5895 & 36.3083 & 0.030299 & 0.311754 & 10.2892 \\
\hline $12^{\circ}$ & 524.6641 & 67.8154 & 0.056512 & 0.437215 & 7.73667 \\
\hline $16^{\circ}$ & 636.0733 & 115.8315 & 0.096661 & 0.530792 & 5.49133 \\
\hline
\end{tabular}

Table.7: aerodynamic coefficients. Spiroid winglet.

\begin{tabular}{|l|l|l|l|l|l|}
\hline Angle of Attack & Lift $(\mathrm{KN})$ & $\operatorname{Drag}(\mathrm{KN})$ & $C d$ & $C L$ & CL/Cd \\
\hline $4^{\circ}$ & 192.7925 & 17.6652 & 0.014625 & 0.159613 & 10.9136 \\
\hline $8^{\circ}$ & 370.9876 & 36.0023 & 0.029759 & 0.307142 & 10.3209 \\
\hline $12^{\circ}$ & 524.2974 & 67.2123 & 0.055641 & 0.434069 & 7.80122 \\
\hline $16^{\circ}$ & 635.7335 & 113.5871 & 0.094039 & 0.526329 & 5.59682 \\
\hline
\end{tabular}

In the tables reproduced above, we can see drag coefficient decreases with wing model wingtip fence and blended winglet. That drag coefficient decrease is measured respect to wing model without winglet. At $4^{\circ}$, the smallest drag coefficient is equal to 0.014578 , wingtip fence. At $8^{\circ}$, it is equal to 0.029759 , blended winglet. At $12^{\circ}$, it equals 0.434069 , blended winglet. Finally, it is equal to 0.094039 at $16^{\circ}$ in blended winglet. Also, we can see circular winglet drag coefficient is higher than wing model no winglet drag coefficient. Circular winglet is able to reduce vorticity magnitude behind wingtips. Therefore, it is able to reduce induced drag coefficient, Cdi. However, induced drag coefficient is one of drag coefficient components. The wing model with circular winglet reference area is larger than without winglet (table1) and that is why circular winglet $C d$ is higher. Thus, the circular winglet shape is not very correct and appropriate. It is not very difficult to reduce wingtip vortex (circular winglet) although to get $C d$ reduction is much complex.

\section{CONCLUSIONS}

The wingtips vortex are developed as a wing is able to produce a ratio $C l / C d$ higher than 1 . If ratio $C l / C d$ is less than 1 , there are no wingtip vortices since the wing is not operating a positive lift. To produce a ratio $\mathrm{Cl} / \mathrm{Cd}$ higher than 1 , the pressure of the lower surface must be higher than the pressure of the upper surface, as can be seen from figures 35 until 38. The difference pressure between lower and upper surface in a wing generates lift and therefore wingtip vortices. The vorticity magnitude increases respect to angle of attack due to the lift increases as the angle of attack goes up.

My wings models are placed on the right of the aircraft, so the vortex rotation moves anticlockwise from a front view. Lower surface is the zone where the pressure takes its highest value, and also in the upper surface the value of pressure is smaller than lower surface. The air goes up from the lower and upper surface and then, the wingtips vortices spin anticlockwise. The maximum value is placed into the wingtip vortex axis and wingtip vortex is turning around on its own axis. Also, vortex widens as it moves away from the wingtip. The vortex lost intensity as we move away from the wingtip.

The function of the winglet is to reduce the size of the vortex. Winglet deflects the vortex far over the wing. The three wing models with winglet are able to reduce the vorticity magnitude in control zones. Therefore, the induced drag Cdi goes down in all the wing models with winglet. However, wing model with circular winglet is not able to reduce drag coefficient $C d$. Circular winglet design was not 
suitable and acceptable. It is not very difficult to reduce wingtip vortex (circular winglet) although to get $C d$ reduction is much complex. On the other hand, wingtip Wing tip fence model works better at low angles of attack. The best winglet is spiroid winglet model since, it is able to reduce drag coefficient and vorticity magnitude fence and blended winglet are able to reduce wing model without winglet drag coefficient.

\section{REFERENCES}

[1] Biomimetic spiroid winglets for lift and drag control- by Joel E. Guerrero, Dario Maestro and Alessandro Bottarofrom : University of Genoa, Italy.

[2] Aerotecnología, 2010. (Quéesun winglet). [online] Available at

< http:// aerotecnologia.blogspot.com/2010/09/quees-un-winglet.html $>$ [Accessed 25 January 2010].

[3] Airline world. Aircraft Winglets. [online] Avaliable at:

< http://airlineworld.

wordpress.com/2008/10/01/aircraft-winglets/ >

[Accessed 25 November 2010].

[4] Aviation Partners Boeing, 2006. Winglets. [online] Avaliable at :< http:// www. aviationpartnersboeing.com/winglets/index.html [Accessed 12 November 2010].

[5] Ardua ad Astra, 2006. Vórtices, winglets y demásparafernaliaaeronáutica. [online] Avaliable at ittp://perarduaadastra.eu/2010/10/vortices-wingletsy-demas-parafernalia-aerodinamica/> [Accessed 22 October 2010].

[6] Boeing, 2009. Advanced Blended Winglets. [online] Avaliable at:

< http://www.b737.org.uk/winglets.htm\#Newsstories> [Accessed 12 January 2011].

[7] Eduardo Nuñez, 2010. Winglets. [online] Avaliable at :< http://www.nurflugel.es/ index.php? option=com_content $\&$ view=article $\&$ id $=109 \% 3$ Awingl ets\&catid $=9 \% 3$ Adise $\&$ Itemid $=1 \quad 2>$ [Accessed 20 October 2010].

[8] Enciclopedia de Física. Resistencia aerodinámica. [online] Avaliable at http://www esacademic.com/dic.nsf/eswiki/278508

[9] George Larson, 2001. How Things Work: Winglets. [online] Avaliable at: $<\quad$ http://www.airspacemag.com/flighttoday/wing.html > [Accessed 1 December2010].

[10] Marty Curry, 2008. Winglets. [online] Avaliable at: $<\quad$ http://www .nasa. gov/centers/dryden/about/Organizations/Technology/ Facts/TF-2004-15-DFRC.html > [Accessed 1 November 2010].

[11] M.A.Soliman, 2009. Viscosity measurement. [online] Available at http://drmohamedsoliman.blogspot.com/2009/09/visco sity-measurement.html [Accessed 25 November 2010].
[12] NASA. Induced Drag Coefficient. [online] Available at: http://www.grc.nasa.gov/WWW/K12/airplane/induced.html > [Accessed 25 January 2010].

[13] Robert Faye, Robert Lapetre, Michael Winter. Aero 17. [online] Available at: <http://www.boeing.com/commercial/aeromagazine/ aero_17/winglet_story.html\#bbj> [Accessed 25Oct 2010].

[14] Tipler, Paul; Mosca, Gene. 2010, Físicapara la ciencia y tecnología. 6th ed. Editorial Reverté S.A.

[15] Tom Bensom, 2010. Four forces on an airplane. [online] Avaliable at :

$<\quad$ http://www. grc.nasa.gov/WWW/K12/airplane/forces.html > [Accessed 1 April 2010].

[16] Tom Bensom, 2009. The lift coefficient. [online] Avaliable at :

$<\quad$ http://www.grc. nasa.gov/WWW/K12/airplane/liftco.html > [Accessed 1 April 2010].

[17] Tom Bensom, 2010. The drag coefficient. [online] Avaliable at :

$<$ http://www.grc. nasa.gov/WWW/K12/airplane/induced.html > [Accessed 1 April 2010].

[18] U.S. Centennial of Flight Commission. Wing Vortices. [online] http://www.centennialofflight.gov/essay/Theories_o f_Flight/Vortex/TH15.htm> [Accessed 18 February 2010].

\section{AUTHOR'S DETAILS}

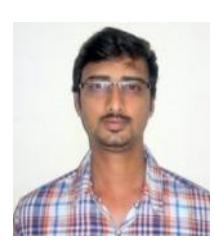

ML Kalyana Chakravarthy, PG Scholar, Marri Laxman Reddy Institute of Technology \& Management, Dundigal, Hyderabad.

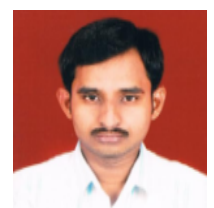

U.Sudhakar, Associate professor, Marri Laxman Reddy Institute of Technology and Management, Hyderabad. Having 5 years of teaching experience. He completed Master's degree in Computational Fluid Dynamics.

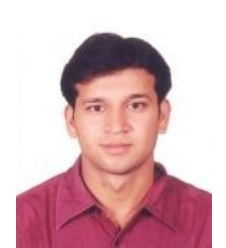

Nirmith Kumar Mishra Assistant professor, Marri Laxman Reddy Institute of Technology and Management, Hyderabad. Having 3.5 years of teaching experience. He completed Master's degree in Aerospace engineering. 